\title{
20. AMAZON FAN MASS-TRANSPORT DEPOSITS AND UNDERLYING INTERGLACIAL DEPOSITS: AGE ESTIMATES AND FAN DYNAMICS ${ }^{1}$
}

\author{
Mark Maslin² and Naja Mikkelsen ${ }^{3}$
}

\begin{abstract}
The Amazon Fan complex comprises two conspicuous features, huge mass-transport deposits (MTDs) and relatively thin interglacial deposits. There are two sets of MTDs: the near-surface MTDs and the deep MTDs. The near-surface MTDs are divided into the Eastern and Western Debris Flows and are capped by Holocene sediments. The deep debris flows are divided into the Unit R MTD in the western Amazon Fan complex, and the deep Eastern MTD (EMTD) in the eastern Amazon Fan complex. Characteristic of the MTDs is the inclusion of reworked glacial and interglacial materials from both the continental slope and the surrounding fan. The relatively thin interglacial deposits below the MTDs are from nannozones CN14b and $\mathrm{CN15a}$, and are thus younger than $475 \mathrm{ka}$. Bio-, seismic-, and magnetostratigraphy and sedimentation-rate constraints have been used to date the top of both the near-surface and the deep MTDs. The deep EMTD was last active at $33 \mathrm{ka}$, whereas the Unit R MTD was last active at about $45 \mathrm{ka}$. It is inferred that the interglacial deposits below the MTDs were formed during oxygen isotope Stages 7, 9, and possibly 11. It is further suggested that the initiation of the MTDs was triggered by climatically induced changes in sea level that may have caused degassing of gas hydrates underlying the MTDs. Moreover, it is speculated that the interglacial deposits underlying the MTDs acted as slip planes for the MTDs.
\end{abstract}

\section{INTRODUCTION}

Many of the world's major rivers have associated deep sea fans, some of which have been drilled by the Deep Sea Drilling Project (DSDP) and Ocean Drilling Program (ODP), for example, the Bengal Fan (Cochran, Stow, et al., 1990), the Mississippi Fan (Bouma, Coleman, Meyer, et al., 1986), and the Amazon Fan (Flood, Piper, Klaus, et al., 1995). Despite the fact that the deep-sea fans may provide unique information on both terrestrial and marine events through time, these fan deposits are often considered of little importance because of their rather inhomogeneous and apparently chaotic nature compared to open ocean sediments.

The Amazon Fan has developed since the early Miocene, as a result of the massive increase in the sediment transport of the Amazon River following the Andean uplift (Castro et al., 1978; Curry, Shackleton, Richter, et al., 1995). At present, and during other interglacial periods, Amazon River terrigenous sediments are deposited predominantly on the inner continental shelf (Flood, Piper, Klaus, et al., 1995). During interglacial periods, pelagic sediments were therefore the chief sedimentary component that accumulated on the Amazon Fan. During glacial periods, the lower sea level caused the out-flow of the Amazon River to feed sediment directly into the fan complex (Damuth and Fairbridge, 1970; Damuth and Kumar, 1975). These rapidly accumulating glacial sediments are therefore largely devoid of pelagic material. Changing sea levels may also have destabilized the shelf and fan sediments, causing many slumps and flows. The most important of these, in terms of volume of sediment, are huge debris flows or mass-transport deposits (MTDs). These deposits have been recognized on seismic lines both near the surface of the Amazon Fan (Fig. 1) and also deep within the fan complex (Figs. 2, 3). Important associated features found beneath the deep MTDs are the interglacial deposits, termed "deep carbonate units," in this paper, which underlie the MTDs. These latter deposits are, volumetrically, not as

${ }^{1}$ Flood, R.D., Piper, D.J.W., Klaus, A., and Peterson, L.C. (Eds.), 1997. Proc. ODP, Sci. Results, 155: College Station, TX (Ocean Drilling Program).

2Environmental Change Research Centre, Department of Geography, University College London, 26 Bedford Way, London WC1H 0AP, United Kingdom. mmaslin@geog.ucl.ac.uk

${ }^{3}$ Geological Survey of Denmark and Greenland, Thoravej 8, DK-2400 Copenhagen NV, Denmark. prominent a feature of the Amazon complex as the MTDs. Yet, they seem to have played an active role in the dynamics of the MTDs and thus the evolution of the fan complex. Moreover, the deep carbonate units provide biostratigraphic age constraints, so that the timing of MTD emplacement and the amount of the stratigraphic column removed by the MTDs can be estimated.

Mass-transport deposits or mass flows/debris flows (MTDs) can cover areas of hundreds of square kilometers (Heezen and Ewing, 1955). Detailed side-scan sonar mapping shows that such deposits constitute a major component of continental margins globally. The surficial parts of some of these deposits (e.g., the Amazon Fan) have been investigated using acoustic and coring methods (e.g., Damuth et al., 1988). Until Leg 155, however, the deeper parts of the MTD deposits as well as the underlying sediments were not accessible.

The objective of this study has been to investigate the biostratigraphic and stable isotopic evidence for the age of the sediment directly above the MTDs, to date the youngest occurrence of the deposits, as well as estimating the age and characteristics of the deep carbonates recovered below the two deep MTDs. These data are essential for understanding the structure and dynamics of the Amazon Fan complex within the late Quaternary and for identifying possible causes of the initiation of the MTDs.

\section{SEDIMENTARY COMPONENTS RECOVERED FROM THE AMAZON FAN}

Leg 155 penetrated MTDs at seven sites and recovered sediment from the entire thickness of the MTDs and underlying sediment at six of these sites (Fig. 2). The two near-surface MTDs, termed the Eastern and Western Debris Flows by Damuth et al. (1988), each cover an area of $\sim 200 \mathrm{~km}$ downslope and $100 \mathrm{~km}$ wide, and are $\sim 100-200$ $\mathrm{m}$ thick (Figs. 1, 2). Two major deep MTDs were cored during Leg 155 (Figs. 2, 3). The first, the "Unit R Debris Flow" (Manley and Flood, 1988), underlies the Upper Levee Complex that was formed during the last glacial, and was recovered at Sites 935, 936, and 944 (Fig. 2). Unit R was found to have levee muds directly below the contact surface. In addition, a sand unit of $\sim 40 \mathrm{~m}$ thickness was recovered below the levee muds at Sites 936 and 944. Below the sandy unit and directly below the levee muds at Site 935, interglacial carbonate- 


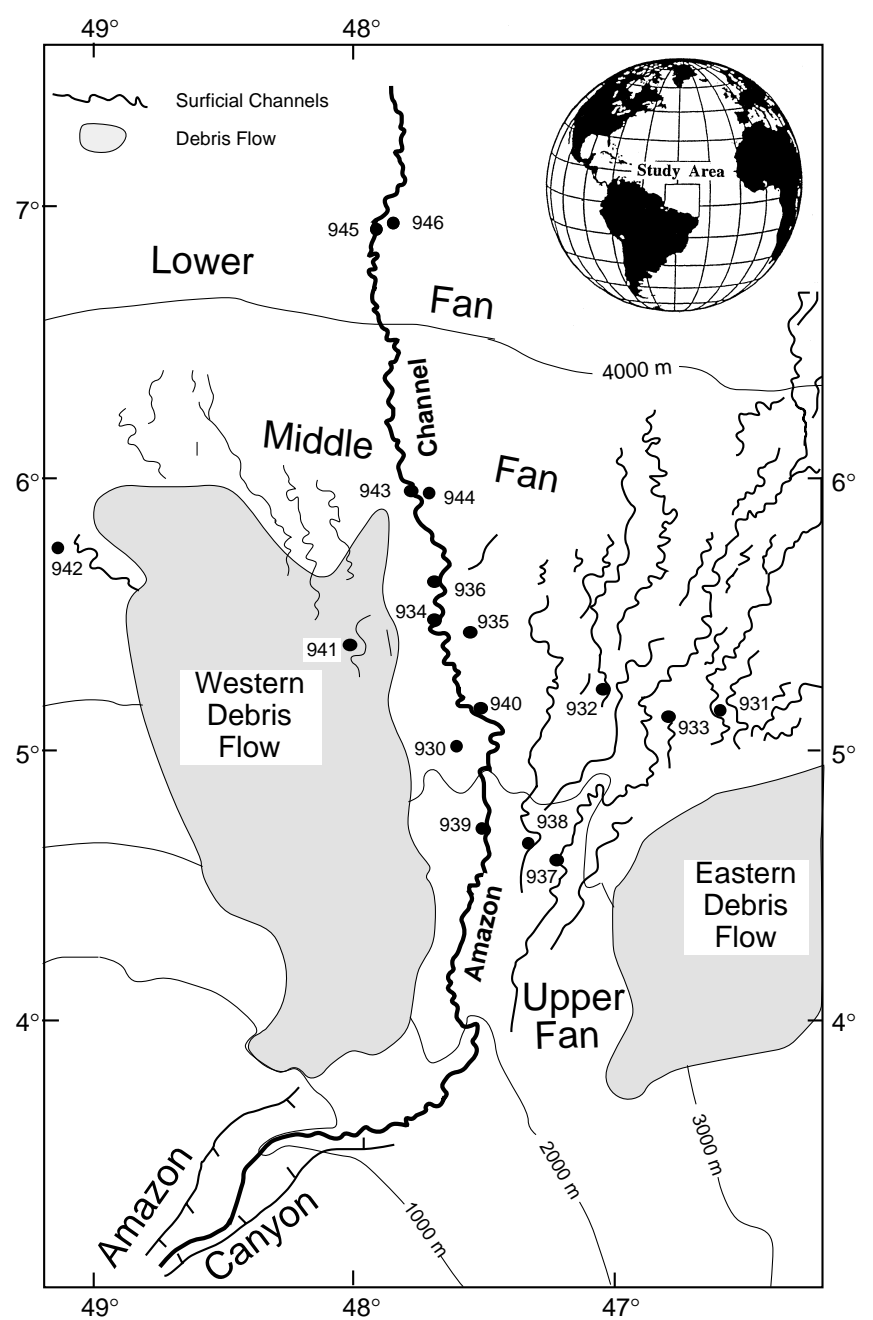

Figure 1. Map of the Amazon Fan and location of Leg 155 sites (from Flood, et al., 1995; modified from Damuth et al., 1988; and Manley and Flood, 1988).

rich units were recovered. The second MTD on the eastern fan, the deep Eastern MTD (EMTD), overlies the crest of the Bottom Levee Complex and was cored at Sites 931 and 933. This ancient MTD was found to have interglacial sediments directly below the contact surface (Fig. 3). The top of an MTD was also penetrated at Site 930, but poor stratigraphy and seismic data were insufficient to link this MTD to either of the other MTDs. Initial assessment suggests, however, that it may be above the Unit R MTD (Flood, Piper, Klaus, et al., 1995).

Initial overview of the stratigraphy of all cored sites was made using shipboard paleo-samples, all of which were re-assessed during subsequent shore-based investigations. Discrete higher resolution samples were taken at key intervals, including boundaries between sedimentary units, calcareous-rich zones and within the MTDs and interglacial deposits found in Sites 931, 933, 935, 936, 942, 944, and 946. Isotope samples were taken every $50 \mathrm{~cm}$ at all sites, and higher resolution samples were taken in calcareous-rich intervals of the seven mentioned sites.

\section{METHODS}

\section{Stratigraphy/Age Assignments}

Age assignments are based on biostratigraphic analyses of calcareous nannofossils and planktonic foraminifers, combined with pale- omagnetic data. Two short geomagnetic features were used for regional correlations: the Lake Mungo Excursion at $\sim 32 \mathrm{ka}$ and the Blake Event at about $105 \mathrm{ka}$ (Cisowski and Hall, this volume). In addition, correlation attempts between the various sites have been supplemented by seismic interpretations (Flood, Piper, Klaus, et al., 1995).

\section{Calcareous Nannofossils}

The nannofossil assemblages were described directly from smear slides prepared from unprocessed sediment. The slides were prepared using standard methods and examined by means of standard light microscope techniques under crossed nicols and transmitted light at $1000 \times$. Critical identifications were confirmed by scanning electron microscopy. The abundance of nannofossils was assigned as: $\mathrm{A}=$ abundant, $\mathrm{C}=$ common, $\mathrm{F}=$ few, $\mathrm{R}=$ rare, and $\mathrm{O}=$ barren.

The standard nannofossil zonal schemes of Bukry $(1973,1978)$, Okada and Bukry (1980), and Thierstein et al. (1977) include two datums for the time interval covered by the drilled sequences, the first occurrence of Emiliania huxleyi at $275 \mathrm{ka}$ and the onset of the E. huxleyi acme at $\sim 85 \mathrm{ka}$ (Fig. 4). The recovered sediments are all younger than $475 \mathrm{ka}$, as Pseudoemiliania lacunosa was not observed. Modifications to improve the resolution of the Pleistocene standard nannofossil scheme have been made by Takayama and Sato (1987) and Raffi et al. (1993). To further refine the subdivision of the Pleistocene Pujos and Giraudeau (1993), Weaver (1993), and Weaver and Thomson (1993) have subsequently established acme zones based on assemblage changes related to the morphotypes of Gephyrocapsa. Due to the rather disrupted nature of the Amazon Fan deposits, these acme zones were the most operational biostratigraphic units to be used in the present study.

\section{Planktonic Foraminifer Assemblages}

Aboard ship, samples were prepared according to the degree of lithification. Unlithified ooze was washed with tap water over a 63$\mu \mathrm{m}$ sieve. Samples with cohesive lumps were first soaked in a weak solution of sodium hexa-meta-phosphate (Calgon), then gently stirred in a beaker with a magnetic stirrer, and then washed over a 63$\mu \mathrm{m}$ sieve. Samples were dried at $65^{\circ} \mathrm{C}$ in an oven. The relative abundance of all key planktonic foraminifer species was estimated in the $>63-\mu \mathrm{m}$ size fraction (Flood, Piper, Klaus, et al., 1995).

The sequential stratigraphy of the Ericson Climatic Zones (Ericson and Wollin, 1956; Ericson et al., 1961) was applied to the younger, more continuous and undisturbed Leg 155 sediment sequences (Fig. 4). The Ericson Climatic Zones are based on the appearance of the Globorotalia menardii complex in predominantly interglacial deposits and its absence in glacial deposits. However, it is noted that the Ericson Zone V, indicated by the presence of the Globorotalia menardii complex, covers oxygen isotope Stages 7 to 11 . The youngest datum based on Atlantic Ocean planktonic foraminifers is the last appearance of Globorotalia tosaensis at $600 \mathrm{ka}$, which was not identified, and the foraminifer assemblages of all sediments recovered that are younger than $600 \mathrm{ka}$. A consistently occurring abundance-shift datum is the disappearance of Pulleniatina obliquiloculata ( $Y p$. obliq.). The P. obliquiloculata datum is diachronous, 36-44 ka (Prell and Damuth, 1978), but is in the present study assigned an age of 40 ka.

\section{Planktonic and Benthic Foraminifer Stable Isotopes}

The oxygen and carbon isotopes of benthic and planktonic foraminifers were measured (see Maslin et al. and Vilela and Maslin, this volume, for full analytical details and isotope data). Two benthic species were selected for analysis, Cibicides wuellerstorfi and Uvigerina sp., and six planktonic foraminifer species, Globigerinoides ruber, $G$. trilobus, G. sacculifer, Neogloboquadrina dutertrei, Pulleniatina obliquiloculata, and Globorotalia truncatulinoides. 


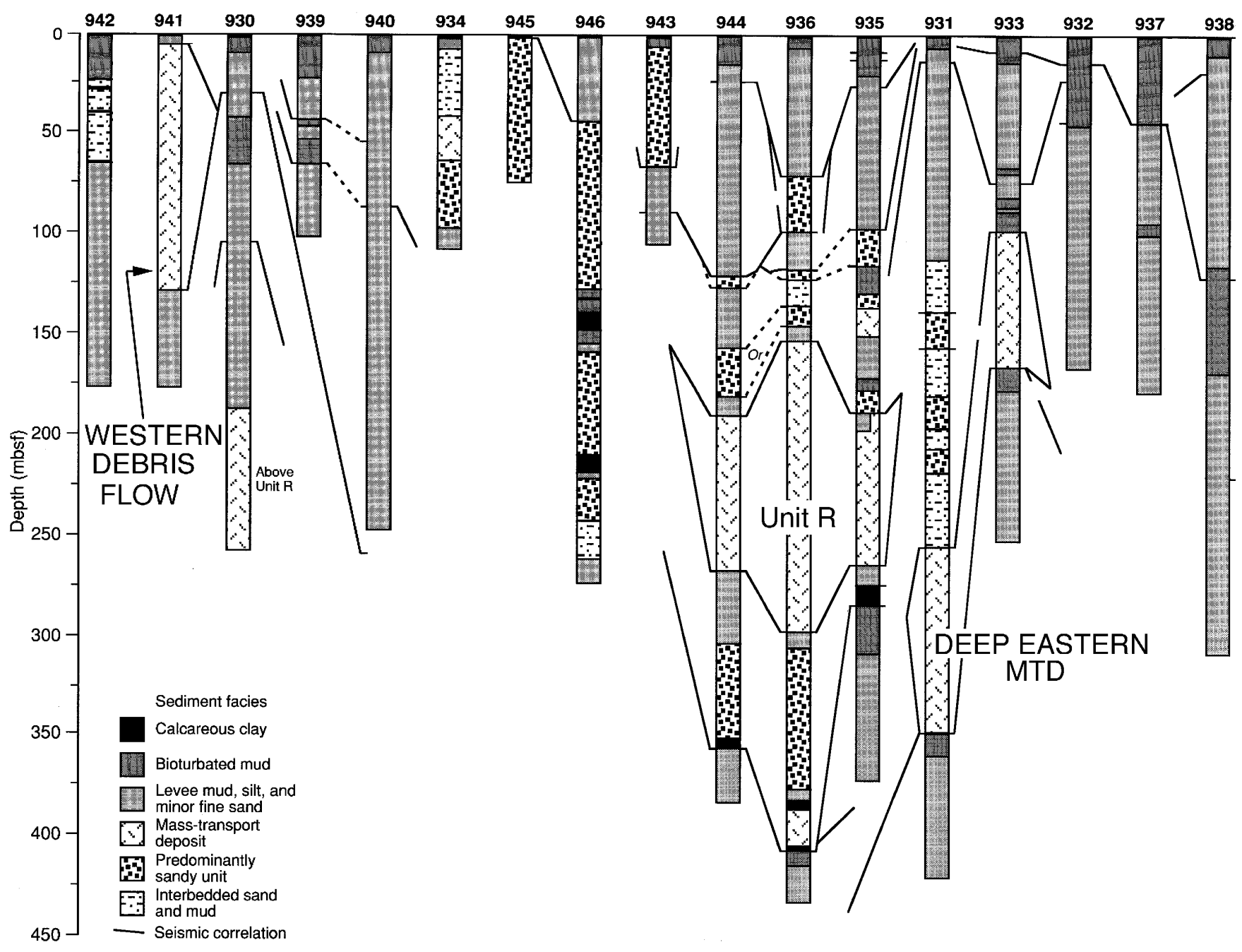

Figure 2. Bar chart indicating sediment types recovered at each of the Leg 155 sites. Complete MTDs and associated calcareous clays were recovered at Sites $931,933,935,936$, and 944 .

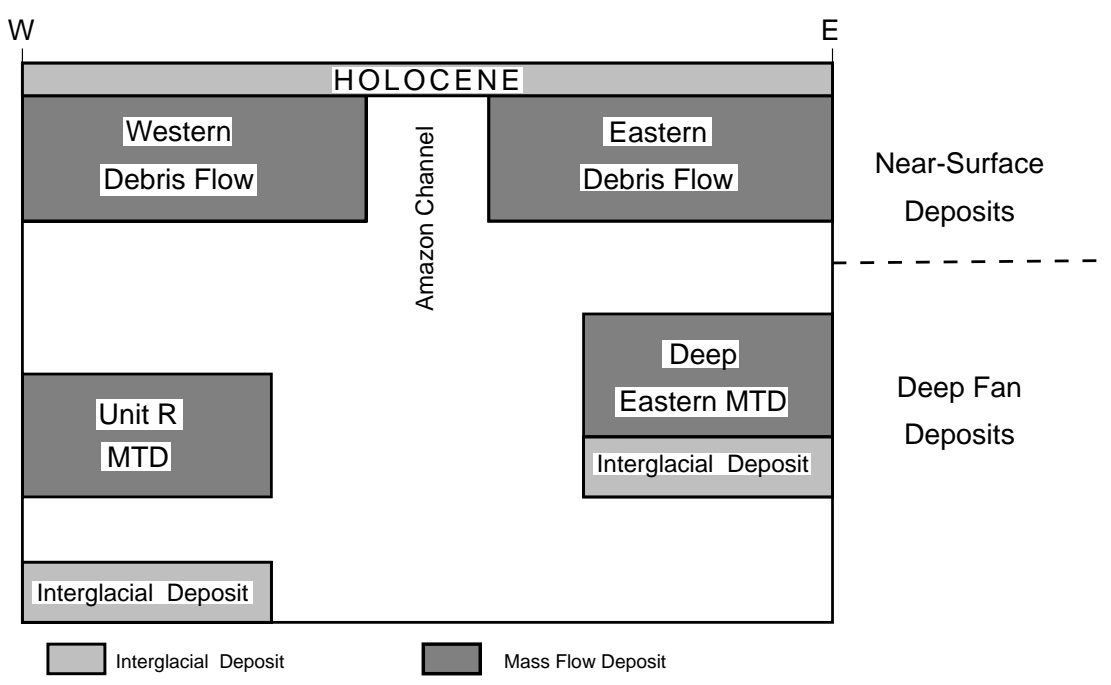

Figure 3. Schematic diagram showing the relationship between MTDs and interglacial hemipelagic deposits (the deep carbonates) of the Amazon Fan (modified from Flood, Piper, Klaus, et al., 1995). 


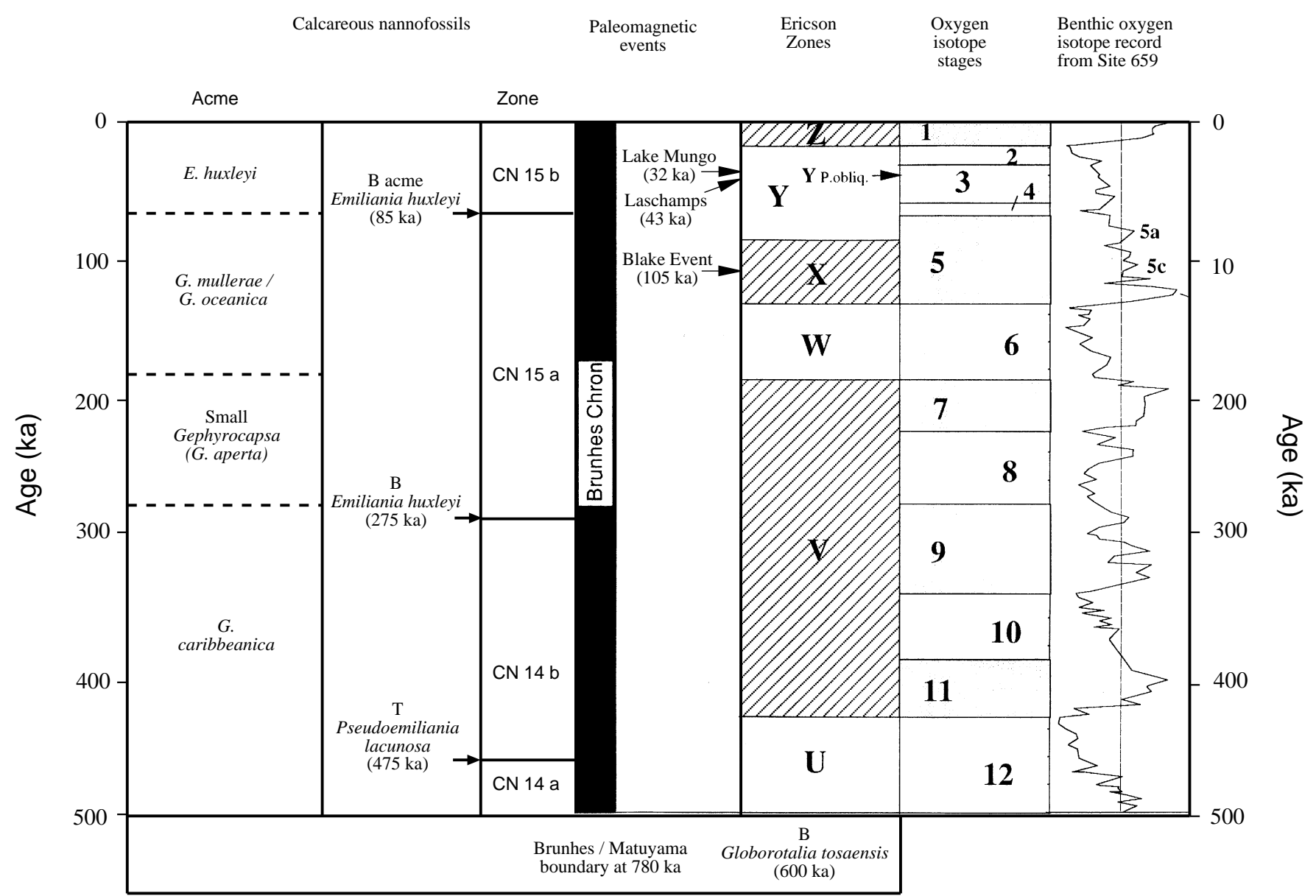

Figure 4. Summary of nannofossil acme zones of Weaver (1993) and Pujos and Giraudeau (1993), nannofossil zones of Okada and Bukry (1980), paleomagnetic events as reported from Leg 155 by Cisowski and Hall (this volume), and planktonic foraminifer-stratigraphy (Ericson Zones of Ericson and Wollin, 1968; Ericson et al., 1961) compared to age and to the classical oxygen isotope stages (from Tiedemann et al., 1994).

\section{RESULTS}

The MTDs were identified primarily by their sedimentary and seismic characteristics (Flood, Piper, Klaus, et al., 1995). The interglacial sediments were identified by their high calcium carbonate contents, the high abundance of calcareous nannofossils (Fig. 5), the presence of the $G$. menardii foraminifer complex, and by the Holocene-like, planktonic and benthic isotope values (Figs. 6-9).

\section{Nannofossils}

The MTDs interrupt the sedimentary sequence and thus sequential stratigraphy based on changes in planktonic foraminifer assemblages, or stable isotopes could not be used for dating of the longer and deeper sequences recovered below the MTDs. The dating of the sediments below the MTDs was therefore done primarily using the nannofossil datums and assemblages, whereas foraminifers were mainly used to date the tops of the MTDs.

Well-preserved calcareous nannofossil assemblages were found only in the interglacial deposits of the Amazon Fan complex and in clasts of interglacial origin within the MTDs. In contrast, the matrix of the MTDs as well as the glacial sediments were almost barren of nannofossils. All interglacial deep carbonates are younger than 475 ka, because of the lack of Pseudoemiliania lacunosa. Small clasts with reworked Miocene and Pliocene nannofossils were found within the MTDs (Flood, Piper, Klaus, et al., 1995).
The overall abundance of nannofossils characterizes the interglacial deep carbonate sequences in the Amazon Fan (Fig. 5). Rich nannofossil assemblages are found in deep carbonate units below Unit R in Sites 935, 936, and 944, and below the deep EMTD in Sites 931 and 933. These interglacial sequences range in thickness from just under $3 \mathrm{~m}$ at Site 944 to almost $8 \mathrm{~m}$ at Site 933. One exception is the much thinner interglacial interval of $0.2 \mathrm{~m}$ at Site 931 .

The nannofossil assemblages of the deep carbonate units represent Zones CN14b and CN15a. The oldest assemblages from Zone CN14b are referred to the G. caribbeanica acme of Weaver (1993) and Pujos and Giraudeau (1993) (Fig. 4). The abundance of small Gephyrocapsa specimens in these low diversity assemblages increases relative to $G$. caribbeanica at the $\mathrm{CN} 14 \mathrm{~b} / 15$ a boundary. In the upper part of $\mathrm{CN} 15 \mathrm{a}$, which is referred to as isotope Stage 5, based on isotope studies of the continuous section in Site 942 off the fan (Showers et al., this volume), the diversity of the nannofossil assemblages increases significantly.

Some of the interglacial sections contain a number of calcium carbonate poor intervals with a high abundance of terrigenous material, and we suggest that these intervals are small turbidites (see "Discussion" section). Delineation of the CN14b/CN15a boundary (first occurrence of E. huxleyi at $275 \mathrm{ka}$ ) in the interglacial deposits is impeded by substantial reworking in at least the top and bottom of the sequences.

The thin deep carbonate unit at Site 931 composes a $0.2 \mathrm{~m}$ section of interglacial material covering both $\mathrm{CN} 15 \mathrm{a}$ and, at the base, assemblages from the $\mathrm{CN} 15 \mathrm{a} / 14 \mathrm{~b}$ boundary. The low abundance of nanno- 


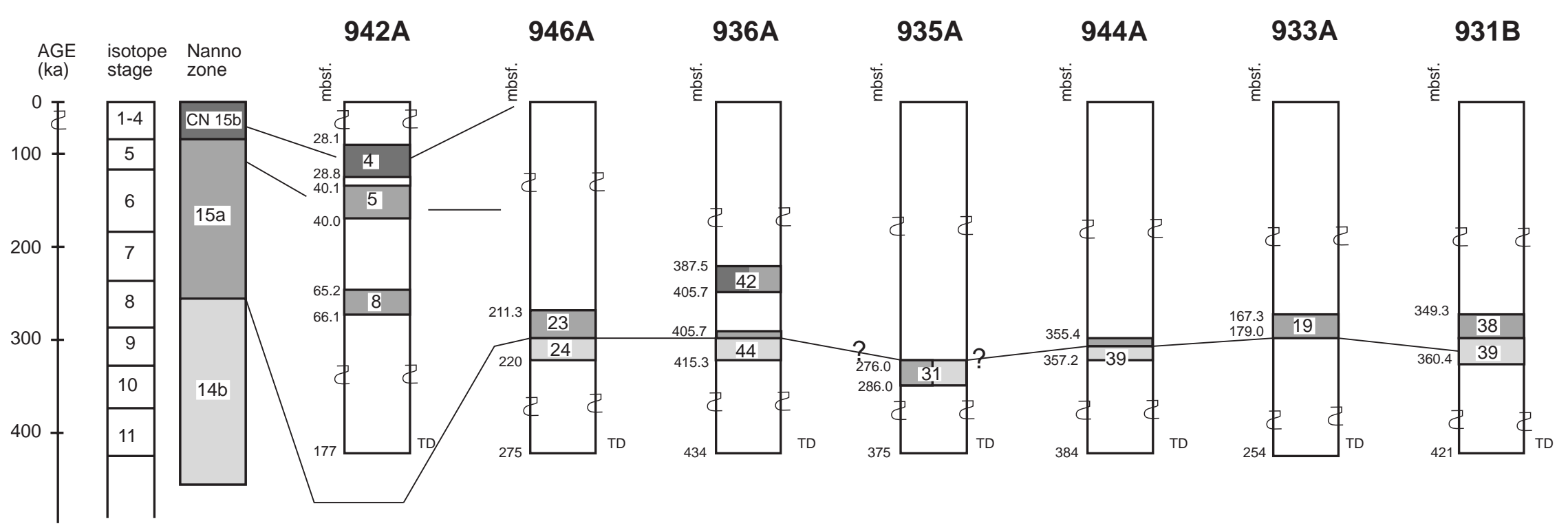

蕰

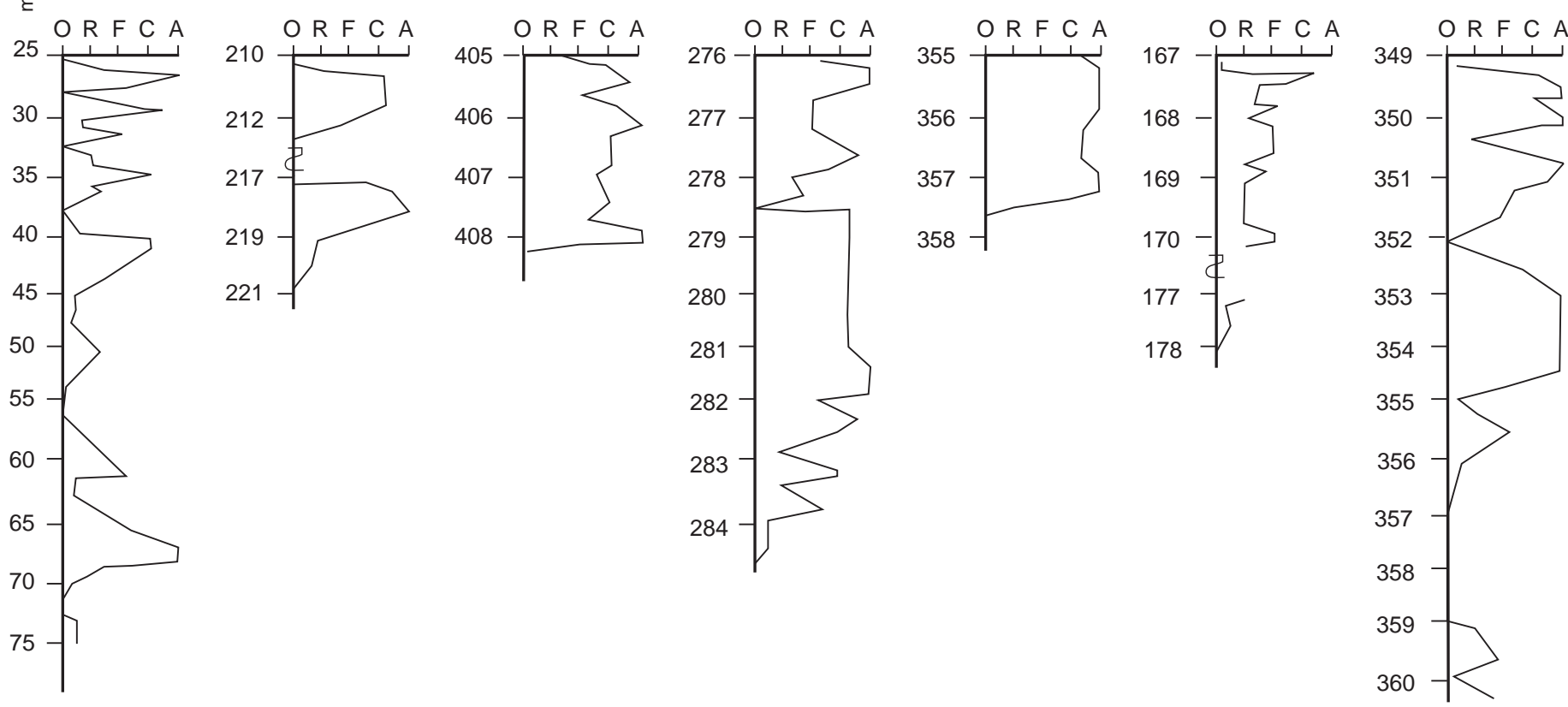

Figure 5. Tentative correlation of the interglacial deep carbonate units of the Amazon Fan sections based on calcareous nannofossils. No obvious succession in the coccolith assemblages (acmes) as reported from the deep ocean (Weaver, 1993; Pujos and Giraudeau, 1993) has been found in the Amazon Fan sequences, which points to a disrupted and, in several cases, fairly reworked nature of the interglacial Amazon Fan deposits. The abundance of calcareous nannofossils is listed as $\mathrm{A}=$ abundant, $\mathrm{C}=$ common, $\mathrm{F}=$ few, $\mathrm{R}=$ rare, $\mathrm{O}=$ barren. Numbers in the schematic holes refer to core numbers and depth intervals (mbsf) of the carbonate units described in Flood, Piper, Klaus, et al. (1995). 
Figure 6. Planktonic foraminifer oxygen isotope records of Site 933.

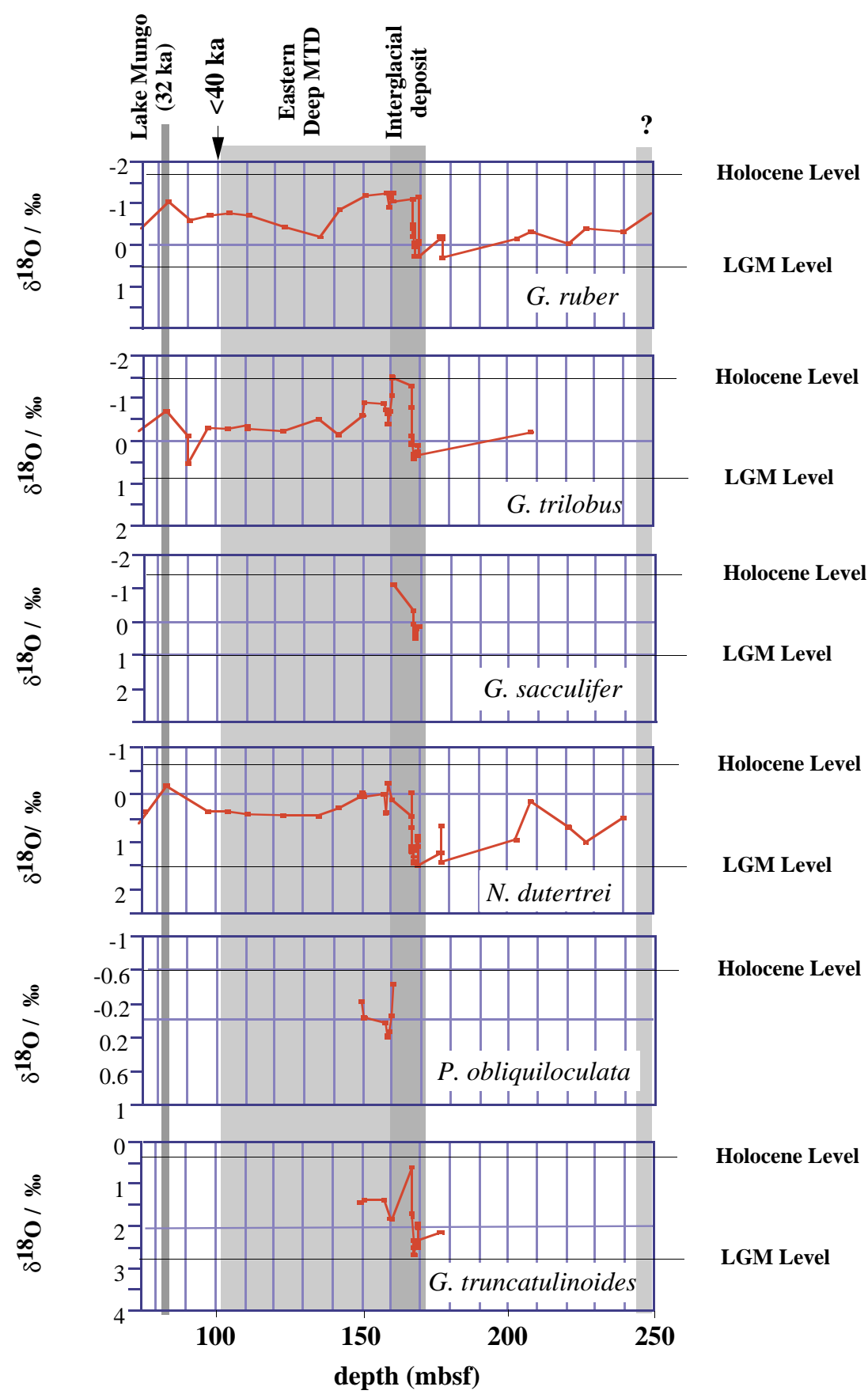

G. oceanica and small Gephyrocapsa of Zone CN15a (Core 155935A-31X). At Site 936, there is evidence for a sandy unit and a small MTD between the Unit R MTD and the underlying interglacial deposit. The top $50 \mathrm{~cm}$ of the interglacial deposit (Core 155-936A$42 \mathrm{X}$ ), just below the debris flow, yields rather poorly preserved assemblages that represent Zone CN15a, whereas the remaining $3.7 \mathrm{~m}$ is well preserved and represents Zone CN14b. The nannofossil assemblages in Core 155-936A-42X are of interglacial origin, but heavy reworking is indicated by the occurrence of older assemblages (CN14b) in between younger (CN15a). At Site 944, there is a sequence of levee muds between the Unit R MTD and the underlying interglacial deposit, where the top $8 \mathrm{~cm}$ represents Zone CN15a and the remaining $1.92 \mathrm{~m}$ represents Zone CN14b (Fig. 5).

Clasts and blocks within the Unit R MTD at Sites 936 and 944 contain nannofossil assemblages from both Zones CN15a and 


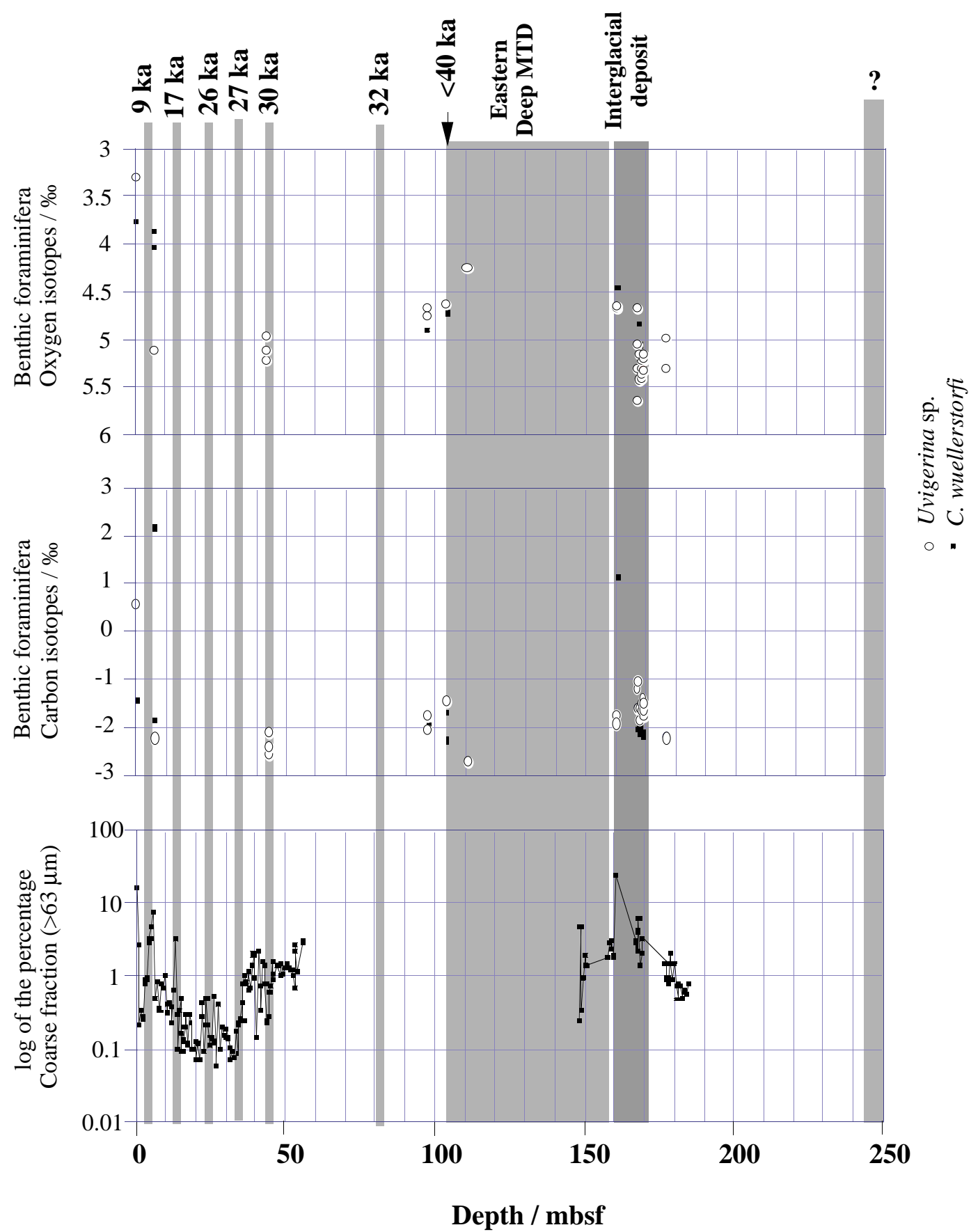

Figure 7. Benthic foraminifer oxygen isotope records of Site 933.

CN14b. Because of the lack of direct contact between the interglacial deposits and the Unit R MTD, it is difficult to date the base of the MTD. It seems likely that it falls between the age of the youngest material incorporated into the Unit R MTD and the underlying interglacial unit. Based on foraminifers, age estimates of the tops of both of the deep MTDs support the nannofossil stratigraphy, which indicates that, in general, the sediment above the MTDs represents nannofossil Zone CN15b, that is, younger than $85 \mathrm{ka}$.

\section{Foraminifers}

The deep carbonate units recovered below both Unit $\mathrm{R}$ and the deep EMTDs clearly have interglacial type planktonic foraminifer assemblages. Many of the samples examined contained the G. menardii complex as well as Globorotalia hexagonus and Globorotalia tumida flexuosa, both of which occur usually only during peak interglacial conditions (Pflaumann et al., 1996). Despite the supposed peak of $G$. tumida flexuosa abundance in oxygen isotope Stage 5e, it was found that the disturbed nature of the deep carbonates prevented any true quantitative estimate of the amount of $G$. tumida flexuosa within any one deposit. The occurrence of $G$. tumida flexuosa and $G$. ruber (pink) suggests that the deep carbonates may be younger than 430 ka (Flood, Piper, Klaus, et al., 1995).

In the deep EMTD, the planktonic foraminifer assemblages of Sites 931 and 933 indicate that the top of the debris flow contains sediment that was originally formed during a peak glacial period. The 


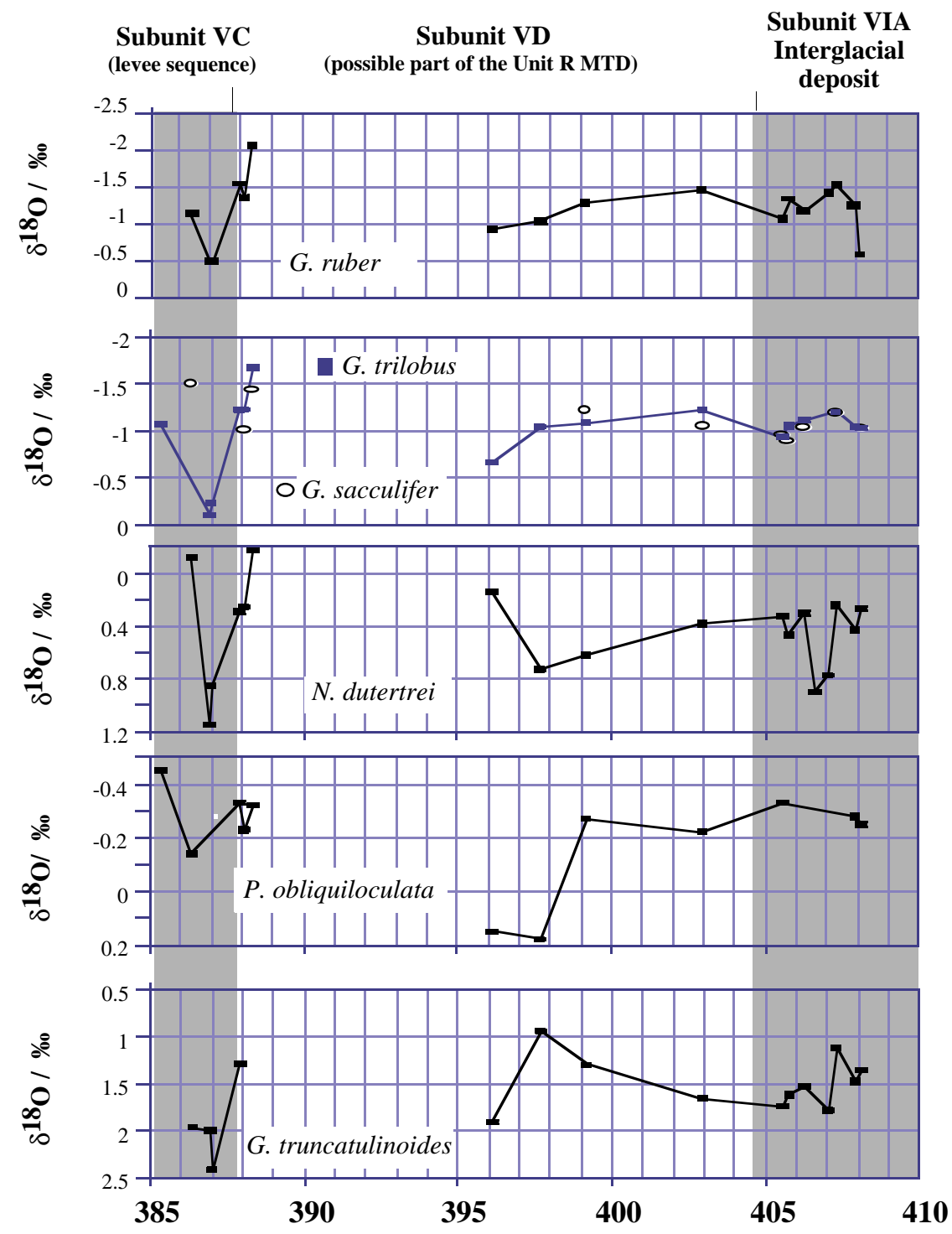

Figure 8. Planktonic foraminifer oxygen isotope records of Site 936

Depth (mbsf)

absence of both $P$. obliquiloculata and the G. menardii complex suggests oxygen isotope Stages 2, 6, 12 or older (Fig. 4). In the lower half of the deep EMTD, $P$. obliquiloculata is abundant, whereas the $G$. menardii complex is absent. This suggests a shift to at least a sediment contribution from material of early glacial age, because $P$. obliquiloculata is indicative of interglacial and early glacial sediments, whereas the G. menardii complex is indicative of full interglacial conditions (Ericson and Wollin, 1956; 1968; Ericson et al., 1961). Near the base of the deep EMTD, G. tumida appears, suggesting either a separate distal interglacial sediment source or reworking of the underlying interglacial material up into the MTD. This biostratigraphic evidence supports the sedimentary observations that the MTD could indeed represent multiple events or block slides (Piper et al., Chapter 6, this volume).

In the Unit R MTD, unlike the deep EMTD, the foraminifer assemblage sequence is different at each site, whereas the assemblages remain constant within the sequences at each site. Unit R at Sites 935 and 944 contains both the $G$. menardii complex and P. obliquiloculata, suggesting a significant input of interglacial and early glacial sediment. However, at Site 936, the G. menardii complex is absent, although $P$. oliquiloculata is present, suggesting an early glacial sed- iment source. It thus seems that a single MTD can contain very differently aged sediments across a distance of less than $15 \mathrm{~km}$ (the distance between Sites 935 and 936).

All five MTDs of the above-mentioned sites contain higher amounts of both bathyal and abyssal benthic foraminifers than found in the usual glacial or interglacial Amazon Fan sediments (Vilela and Maslin, this volume). Further details of the benthic foraminifers in the MTDs are given in the "Discussion" section (this paper) and in Vilela and Maslin (this volume).

\section{Stable Isotope Results}

The oxygen isotope records of planktonic foraminifers in the deep EMTD and the underlying interglacial deposit at Site 933 are shown in Figure 6. The planktonic foraminifer oxygen isotope results indicate that the interglacial deposit has lighter values than the underlying glacial levee muds. However, these values do not in general reach the same level as those characteristic of the Holocene. This may indicate either that the deposit represents the very beginning or end of an interglacial period or, as previously suggested, that there was reworking of heavier glacial material into the deposit. We suggest that both 


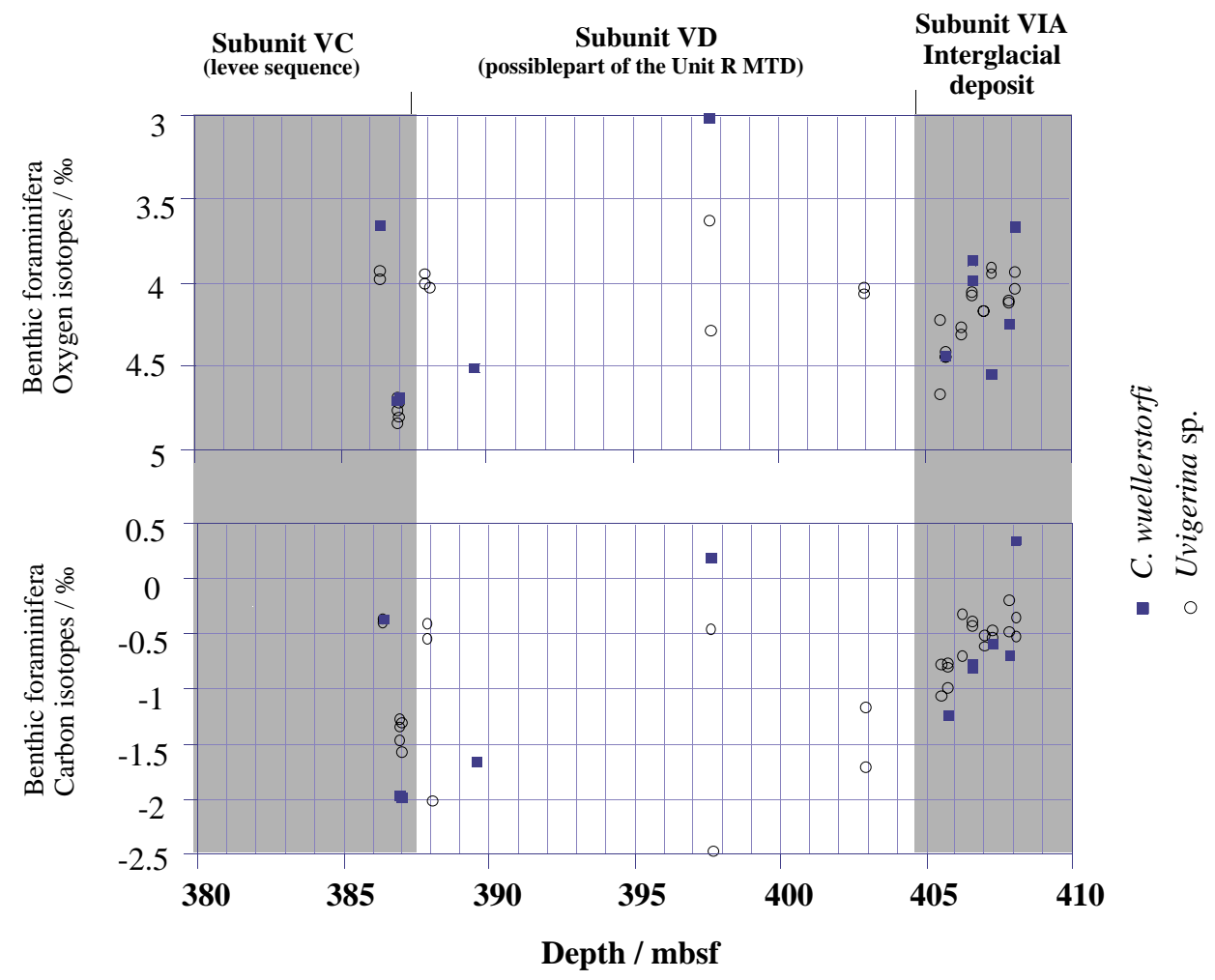

Figure 9. Benthic foraminifer oxygen isotope records of Site 936. Symbols as in Figure 7. are likely, first because the nannofossil evidence suggests that the interglacial deposit is a curtailed sequence. Second, the reworking hypothesis is supported by the benthic foraminifer oxygen isotope results, as only glacial values were recorded in the interglacial deposit (Fig. 7). It is also important to note that the oxygen-isotope values of the reworked benthic foraminifers are much heavier (by up to $0.5 \%$ ) than those found during the last glacial maximum (LGM). This indicates that they originated from a more intense glacial period (e.g., oxygen Stage 6).

The sparsity of planktonic foraminifers in the deep EMTD means that it was only possible to obtain isotope records of G. ruber, G. trilobus, and $N$. dutertrei. All three records indicate that the foraminifers in the MTD have oxygen-isotope values intermediate between Holocene and LGM values (Maslin et al., this volume). This either means that sediments from the deep EMTD were formed mainly during early oxygen Stage 3 (or another early glacial period) when the sea level was still relatively high or that there was mixing between interglacial and glacial materials within the MTD. Abyssal benthic foraminifers are absent from the deep EMTD, except for the very top, where their isotopic values were heavier than for the LGM. These data may again be interpreted as reworking of older material or secondary calcification of the tests.

The interpretation of sedimentation patterns at Site 936 is more complicated than at Site 933 because of poor core recovery and the presence of sediments identified as levee mud sequences between the Unit R MTD and the underlying interglacial deposits. In Cores 155936A-41X through $45 \mathrm{X}$, an interval of levee muds was recovered overlying a short MTD, which in turn overlies an interglacial deposit on top of more levee muds (Flood, Piper, Klaus, et al., 1995). What is uncertain is whether the small MTD is part of the Unit R MTD despite the presence of a levee mud sequence between them. The planktonic foraminifer-oxygen isotope data suggest that only the top of Subunit VD (388 mbsf) contains foraminifers that were formed during interglacial conditions (Fig. 8). This suggests either that the foraminifers in the interglacial deposit were reworked or that the interglacial deposit was formed during a period when the sea level was not at its maximum height. Reworking is supported by nannofossil evi- dence. Moreover, the planktonic foraminifers within the Subunit VD MTD have values similar to those of the underlying interglacial deposit (Fig. 8), indicating reworking of the interglacial material into the MTD. The benthic foraminifer oxygen isotope values in Subunits VC, VD, and VIA are similar, indicating values similar to those found during the LGM (Fig. 9). This indicates a significant amount of reworking in all three subunits.

The G. sacculifer oxygen isotope data from the main Unit R MTD (Showers et al., this volume) again indicate that the sediment was either formed during a glacial interval with a relatively high sea level, or that there is a substantial mixing between interglacial and glacial materials within the Unit R MTD.

\section{DISCUSSION}

\section{Problems of Dating the Interglacial Deposits}

Age control for the MTDs is based on the fossil-bearing hemipelagic sediments found above and below the MTDs. The deep EMTDs are resting on interglacial deposits, whereas the Unit R MTD is separated from the interglacial deposits by up to $75 \mathrm{~m}$ of levee mud sediment (Flood, Piper, Klaus, et al., 1995). Thin carbonate sequences and clasts are, however, also found within sections considered to be MTDs (e.g., within Subunit VD in Hole 936A). The question therefore arises whether the deep interglacial deposits drilled in the Amazon Fan complex are actually allochthonous, as some nannofossil datums occur randomly within some of the deep carbonate units and benthic isotope data show a mixture of interglacial and glacial values within the same deposits. However, sedimentological evidence from shipboard analyses suggests that the interglacial deposits are relatively undisturbed with no signs of internal distortion and are thus in place (Flood, Piper, Klaus, et al., 1995). Therefore, we consider in general that the deep carbonates are in situ.

Another problem is whether all the sediment within the deep carbonates are pelagic. Assuming that an average interglacial period in the late Quaternary lasts about $40 \mathrm{ka}$, and that open ocean sedimentation rates in the low-productivity tropical western Atlantic range 
from 1 to $5 \mathrm{~cm} / \mathrm{k} . y$. , then the interglacial deposits found in the Amazon Fan complex should be at maximum $2 \mathrm{~m}$ thick. At Sites 933, 935, and 936, the deep interglacial sediments recovered below the MTD are between 3 and $8 \mathrm{~m}$ in thickness (Flood, Piper, Klaus, et al., 1995). This suggests that a considerable amount of the deep carbonates may be reworked material or represent a mixture of glacial/interglacial materials as suggested by the benthic $\delta^{18} \mathrm{O}$ values. We suggest that the reworked material in the deep carbonates is present in the form of fine-grained turbidites similar to those documented in the last interglacial section (isotope Stage 5) recovered at Site 942, where more than half the interglacial sediments have been documented to be fine turbidites (Showers et al., this volume). The presence of turbidites in the deep interglacial deposits can explain the highly variable abundances in these deposits of nannofossils (Fig. 5) and complicates the dating of these deposits. The significant reworked component appears to be confirmed by the benthic foraminifer oxygen isotope data at Sites 933 and 936 (Figs. 7, 9). In both cases, there are benthic foraminifers with peak glacial oxygen-isotope values in the middle of the interglacial sequences.

The short deep carbonate sequence $(0.2 \mathrm{~m})$ recovered at Site 931 (Fig. 5) apparently represents the very bottom of an interglacial deposit in contact with an underlying glacial sequence. This stratigraphic situation suggests a mechanism by which the MTDs are sliding into position on a weaker and less-consolidated substratum of the carbonate-rich interglacial deposits. This sliding mechanism would incorporate interglacial material in the lower part of the MTDs, as seen in Sites 933, 935, 936, and 944 (Flood, Piper, Klaus, et al., 1995).

\section{Inferred Oxygen Isotope Stages}

The nature of the Amazon Fan complex does not allow for a traditional subdivision of the sediments based on either biostratigraphy, sequence stratigraphy, or isotope stratigraphy because of the disrupted nature of the sedimentary record. Nevertheless, a combination of biostratigraphic data, sedimentologic data, and seismic data is used along with stable isotope data to establish the geochronology of the fan, which we tentatively place into an isotope stage framework.

The predominance of the Zone CN15a assemblage at Sites 931 and 933 with $\mathrm{CN} 14 \mathrm{~b}$ material at the base suggests that this interglacial deposit was largely formed during either oxygen isotope Stage 5 or 7. Similarly, the basal part containing CN14b material either represents Stage 9 or 11, or the reworking of Stage 9 or 11 material into Stage 5 or 7 . Since CN14b material is found at the base of the interglacial deposits at both sites, it is most likely that the interglacial deposits are from Stage 7 . However, considering that the CN14b/15a boundary lies close to the base of isotope Stage 8 (Weaver, 1993; $\mathrm{Pu}$ jos and Giraudeau, 1993), another interpretation could be that the CN15a sequence represents the base of isotope Stage 8 and CN14b represents the interglacial Stage 9. In the present study, the first interpretation is used. The nannofossil assemblages from the deep carbonate of Sites 931 and 933 are distinctly different from the isotope Stage 5 interglacial assemblages at Site 942. This is consistent with the above interpretation.

Sites 935, 936, and 944 all have deep carbonate units below the Unit R MTD. However, unlike Sites 931 and 933, there is not a direct contact between the MTD and the underlying interglacial deposits. At Site 936, the top $50 \mathrm{~cm}$ of the interglacial deposit represents Zone CN15a, whereas the remaining $3.7 \mathrm{~m}$ represents CN14b. At Site 944 , the top $8 \mathrm{~cm}$ of the interglacial deposit represents Zone CN15a and the remaining $1.92 \mathrm{~m} \mathrm{CN14b}$ (Fig. 5). We infer that the predominance of the $\mathrm{CN} 14 \mathrm{~b}$ nannofossil assemblage dates the interglacial deposit as either oxygen isotope Stage 9 or 11, but most likely Stage 9. The interglacial deposits of Site 935 represent a random mixture of CN14b and CN15a nannofossil assemblages. Seismic evidence, however, suggests that the interglacial deposit at Site 935 is stratigraphically below those at Sites 936 and 944 . It is therefore suggested that the interglacial deposits at Sites 936 and 944 may have been formed during oxygen isotope Stage 9, whereas the interglacial deposits at Site 935 are tentatively referred to isotope Stage 11, although they may just as well represent Stage 9 or 7 with a reworking of older sediments into the sequence.

Clasts and blocks within the Unit R MTD at Sites 936 and 944 contain nannofossil assemblages from both Zone CN15a (supposedly Stage 7/8) and CN14b (Stage 9 or 11). Because of the lack of a direct contact between the interglacial deposits and the Unit R MTD, it is difficult to date the base of the MTD. Our best estimate is that it must lie between the youngest material incorporated into the Unit R MTD and the underlying interglacial unit. We therefore suggest that at Sites 936 and 944, the base of the Unit R MTD is dated between oxygen isotope Stages 7 and 9 (Fig. 10).

\section{Timing of the MTD Activity}

One of the more intriguing questions to arise from the Amazon Fan drilling is what caused the formation of the massive near-surface and deep MTDs. To adequately address this question, it is important to establish the timing of the emplacement of each MTD.

The paleomagnetic Lake Mungo Excursion was observed above the deep EMTD at both Sites 931 and 933 (Cisowski and Hall, this volume), making the MTD older than $32 \mathrm{ka}$. The absence of both the $G$. menardii complex and $P$. obliquiloculata in the foraminifer assemblages from the intervening sediment between the Lake Mungo Excursion and the top of the MTD suggests that the MTD may be younger than $40 \mathrm{ka}$. Assuming that the foraminifer assemblages are complete, this suggests that the deep EMTD was last active between 30 and $40 \mathrm{ka}$. The sedimentation rate between the paleomagnetic intensity-variation datum of $30 \mathrm{ka}$ and the Lake Mungo Excursion at 32 $\mathrm{ka}$ (Cisowski and Hall, this volume) at Site 933 is $\sim 15 \mathrm{~m} / \mathrm{k}$.y. (Fig. 6). Assuming that the sedimentation rate below the Lake Mungo is similar to that above, then the top of the deep EMTD is no older than 33 ka.

The Unit R MTD is harder to date because the significant highamplitude reflector packet (HARP) units above the MTD (Flood, Piper, Klaus, et al., 1995) prevented detection of the Lake Mungo Excursion at any of the three sites. However, at Sites 935 and 936, pockets of hemipelagic sediment were found within the HARP unit. These hemipelagic sequences contained $P$. obliquiloculata but no G. menardii complex, suggesting that these sections are between 40 and 85 $\mathrm{ka}$. In the case of Site 936, hemipelagic mud is in contact with the MTD, suggesting that the Unit R MTD was last active between 40 and $85 \mathrm{ka}$. At Site 935 there is direct contact between levee muds and the MTD. Assuming this is not an erosional contact, and that the average late glacial sedimentation rate for Site 935 is calculated to $4 \mathrm{~m} /$ k.y., then the top of the Unit R MTD is $\sim 45 \mathrm{ka}$.

The ages of the tops of both deep MTDs are supported by the nannofossil stratigraphy, which indicates that in general, the sediment above the MTDs is from nannofossil Zone CN15b, (i.e., younger than $85 \mathrm{ka}$ ). The key inference, however, is that emplacement of the two deep MTDs occurred at different times, that is, before and after $40 \mathrm{ka}$ respectively.

Damuth et al. (1988) and Showers and Bevis (1988) have shown that the Eastern and Western near-surface Debris Flows are capped by Holocene sediments. Detailed sampling of the Holocene sediments above the Western Debris Flow at Site 941 indicates the presence of P. obliquiloculata, G. tumida, and G. menardii (Flood, Piper, Klaus, et al., 1995). As there is no interglacial material found in the top $25 \mathrm{~m}$ of the underlying MTD, then it seems that the Western Debris Flow was last active during the early Holocene. The presence of $P$. obliquiloculata dates the assemblage as younger than $11 \mathrm{ka}$, whereas $G$. tumida dates the sediment younger than $7.5{ }^{14} \mathrm{C}$ ka (Flood, Piper, Klaus, et al., 1995). The presence of G. menardii further dates the top of the MTD as younger than $6.3{ }^{14} \mathrm{C}$ ka. Sedimen- 


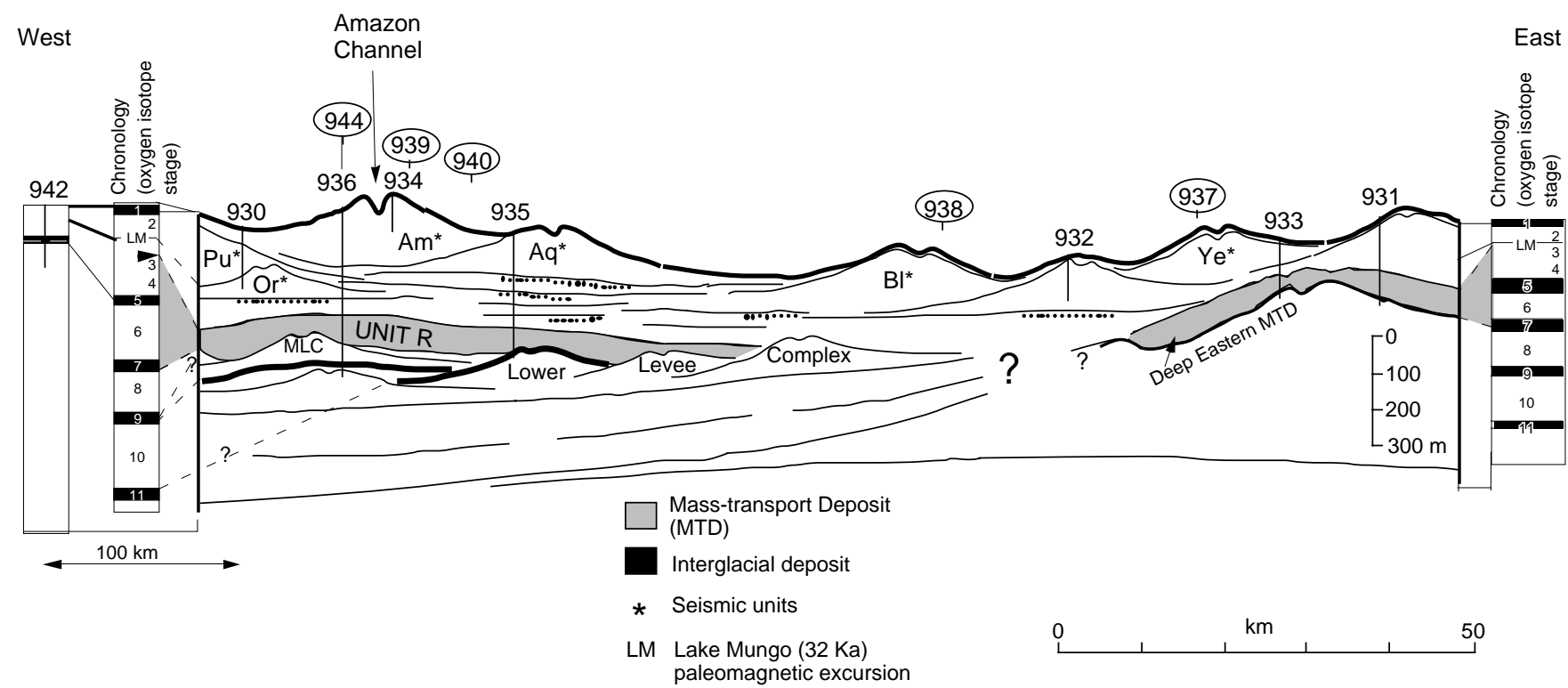

Figure 10. Theoretical model of the overall stratigraphy of the MTD units and interglacial deep carbonates drilled on the Amazon Fan. Initial unit correlations are based on seismic stratigraphy (Flood, Piper, Klaus, et al., 1995).

tological evidence at Site 941 indicates that the Holocene section contains a number of turbidites (Flood, Piper, Klaus, et al., 1995), suggesting that the very rarely found $G$. menardii and $G$. tumida may have been reworked. However, oxygen isotope records of $G$. sacculifer from Site 941 (Showers et al., this volume) and V18-20 (Piper et al., Chapter 6, this volume) indicate a consistent value of between $0.2 \%$ and $0.3 \%$ above the Western Debris Flow. When examined in the context of the whole oxygen isotope record, it suggests that the top of the Western Debris Flow is $\sim 14$ ka (Showers et al., this volume). Therefore, a conservative estimate for the age on top of the Western Debris Flow is between 11 and 14 ka, (i.e., during Termination I).

Seismic data suggest that the near-surface Western and Eastern Debris Flows are coeval (Damuth et al., 1988; Flood, Piper, Klaus, et al., 1995), and thus it appears that they were last active during Termination I.

Important for the understanding of the cause of the MTDs is to establish whether each MTD represents single or multiple events, and in the case of multiple events if they co-occur or are widely separated in time. If the MTDs do represent multiple events occurring over a long period of time, then there could be various causes for each of the successive events. The sedimentological characteristics, the consolidation properties, and the biostratigraphy (Flood, Piper, Klaus, et al., 1995; Mikkelsen and Maslin, this volume) of the MTDs indicate that there are distinct blocks or units present within each of the debris flows. Given their stratigraphic position, they likely represent discrete events. It is nevertheless still under debate whether these blocks represent a single or a number of mass-transport events separated in time.

\section{Scale and Sediment Sources of the MTDs}

The MTDs each cover an area of up to $20,000 \mathrm{~km}^{2}$ and reach a maximum thickness of $200 \mathrm{~m}$. Assuming the standard density of deep-sea sediments, then each of the MTDs consists of up to $5 \times 10^{4}$ Gt of sediment. Milliman and Meade (1983) calculated the present sediment discharge of the Amazon River as 0.9 Gt per year. So each MTD represents a 50 ka sediment package under present conditions. Important unanswered questions are: (1) How did the Amazon sediment discharge change in the past? and (2) How much of each MTD is reworked from the levees compared to original material brought down from the continental shelf and/or slope?

Two hypotheses have been presented to explain the sources of the MTDs. Some seismic data suggest that the MTDs represent channellevee sediments that have been deformed essentially in situ (Piper et al., Chapter 6, this volume). In contrast, based on analyses of benthic foraminifer data, Vilela and Maslin (this volume) suggest that a significant amount of the MTD originated at middle to upper bathyal depths with some shelf contributions.

Evidence to support an in situ formation of the MTD comes from the incorporation of carbonate-rich interglacial sediments at the base of some of the MTDs (Piper et al., Chapter 6, this volume). Additional evidence comes from lithologic similarities between some of the MTD blocks and the fine-grained levee deposits, including a distinctive clay mineral assemblage reported from Site 931 (Lopez et al., this volume). However, these observations are not inconsistent with a possible distal source for the MTDs. We suggest that the carbonaterich interglacial deposits have acted as the main slip plane for emplacement of the MTDs onto the fan, and that incorporation of interglacial sediment within the base of the MTDs should therefore be expected. The transport of such large amounts of sediment from a distal area has been reported from other continental margins (Weaver and Thomson, 1993), and could also be expected to include blocks torn off the adjacent levees.

\section{Possible Causes of the MTDs}

Our previous discussion suggests that all of the drilled Amazon Fan MTDs were emplaced either during the last glacial or during the last glacial/interglacial transition. We suggest that climatically induced changes in sea level could have caused the formation of MTDs. A lowering of sea level would be expected to expose and undercut sediment piles on the continental shelf and slope by reducing the weight of the water column above, and by causing Amazon River sediment to be funneled progressively more directly onto the fan. This sea-level effect may have been further exacerbated by decompression of gas hydrates reported from the shelf area (Flood, Piper, Klaus, et al., 1995). Evidence for the presence of gas hydrates was found in a number of the sites on the Amazon Fan (Soh, this volume). The role of sea level in initiating MTD emplacement is further sup- 
ported by the fact that both of the deep MTDs contain continental shelf and slope benthic foraminifers (Vilela and Maslin, this volume). This suggests that the initial failure of the sediment column must have begun at a relatively shallow water depth. Moreover, the timing of the two MTDs at $33 \mathrm{ka}$ and $45 \mathrm{ka}$ corresponds to a period of rapidly lowering sea level (see Fig. 11), especially if compared to the continentally derived sea-level curve of Flood, Piper, Klaus, et al. (1995). It can be argued that MTDs caused by earlier shifts in sea level (such as during oxygen isotope Stage 4 and early Stage 3), are not as likely to leave an imprint on the sedimentary record, as these changes would be overprinted by or incorporated into the deep EMTD and the Unit R MTD.

The sea level/climate driven hypothesis is further supported by the occurrence of the near-surface Eastern and Western Debris Flows during Termination I. These shallow MTDs may originate from a rising sea level that was undercutting the exposed sediment on the continental shelf, causing it to fail. A further suggestion is that this episode was linked to climate change coupled with the deglaciation of the Andes. Tropical ice core data from Peru indicate that the Andes deglaciated between 13 and 15 calendar ka (Thompson et al., 1995), similar to the estimated age of the oldest sediment above the Eastern and Western Debris Flows. Maslin et al. (this volume) suggest that the Andean deglaciation may have caused a surge in the outflow and/ or an increase in the sediment load of the Amazon River. The additional sediment would have been deposited onto the continental shelf and slope sediments, which were already being undercut by the rising sea level. This idea is supported by the high abundance of continental shelf and slope benthic foraminifers found in the Western Debris Flow at Site 941 (Flood, Piper, Klaus, et al., 1995). In addition, clasts containing Miocene and Pliocene nannofossil assemblages were found in the Western Debris Flow (Flood, Piper, Klaus, et al., 1995), which could only have come from the continental shelf via erosion. Between 13 and $15 \mathrm{ka}$, the planktonic foraminifer-carbon isotope records at Sites 933, 932 (Maslin et al., this volume), and 942C (unpubl. data) indicate a huge negative deviation (of up to $2 \%$ ). Maslin et al. (this volume) have interpreted this carbon isotope excursion in two ways, either: (1) an increase in the amount of Amazon Basin-derived light terrestrial carbon in the surface waters of the tropical western Atlantic, thus supporting the Andes deglaciation theory; or (2) significant amounts of gas from gas hydrates in the water column, which supports the sea-level-gas-hydrate-causation theory.

There are other possible causes of the MTDs. "Critical sediment loading" could be an example of a triggering mechanism independent of sea-level changes. The huge sedimentation rates during the last glacial ( 1 to $>50 \mathrm{~m} / \mathrm{k}$.y.) imply that the Amazon Fan sediments may easily become over-consolidated, making them prone to failure. This failure would most likely have occurred along a layer of weakness, such as the carbonate-rich interglacial deposits or the levee muds (Flood, Piper, Klaus, et al., 1995). This idea is partially supported by the observation that many of the MTDs lie directly on top of or near an interglacial deposit (Sites 931 and 933), whereas the remainder lie on top of levee muds (Sites 935, 936, and 944). Moreover, physical properties and water-content analysis of the MTDs suggest that a significant amount of the MTD sediments are over-consolidated (Flood, Piper, Klaus, et al., 1995). However, the critical sediment-load hypothesis is not entirely independent of sea level, as sea level controls the amount of Amazon River sediment that flows into the fan complex. It may even be argued that sea-level change is ultimately the triggering mechanism, and that sediment loading on its own could not cause such widespread and massive failure. Other possibilities include that the MTDs are events triggered by submarine earthquakes.

The ultimate cause of the MTDs is still being debated, and at present, there seems to be no one clear explanation. We consider that evidence from the Amazon Fan suggests that climatically driven changes in sea level are the most likely triggering factor in the formation of the MTDs. Factors such as gas hydrates, critical sediment loading, and submarine earthquakes may represent other contributing

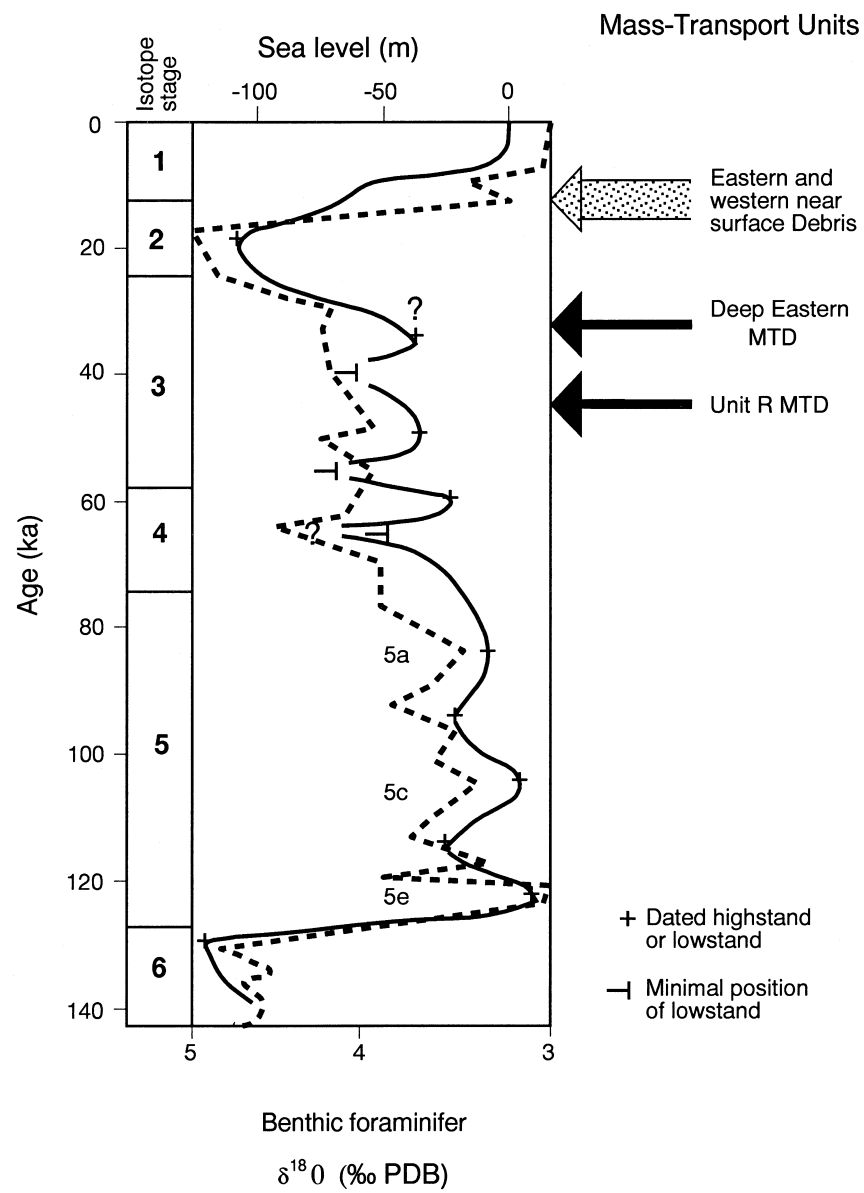

Figure 11. Comparison of the terrestrially derived record of "eustatic" variations in sea level (Flood, Piper, Klaus, et al., 1995), and the benthic foraminifer oxygen isotope record (Tiedemann et al., 1994), with the timing of the MTDs drilled on the Amazon Fan. Note that because of the non-linear response of the oxygen isotope record, the sea-level changes between $20 \mathrm{ka}$ and $50 \mathrm{ka}$ are more clearly defined in the composite terrestrially derived sealevel curve. The deep EMTD and Unit R MTD seem to occur during periods of sea-level lowering, whereas the Eastern and Western near-surface debris flows occur during a period of rapid rise in sea level (adapted from Mikkelsen and Maslin, in press).

factors, which to some extent may also ultimately be influenced by sea-level and climate changes. Further research on the Amazon Fan sediments and other deep-sea fan deposits will hopefully elucidate the role of sea-level control on the growth and development of the deep-sea fans.

\section{CONCLUSIONS}

1. All sediments recovered during Leg 155 that were not included as clasts in an MTD are younger than $475 \mathrm{ka}$.

2. Interglacial deposits recovered from beneath the major MTDs cover the interval of nannofossil Zones CN14b to CN15a (475-85 ka). Interpretation of data and analyses of the reworking characteristics of these deposits suggest that the interglacial deposits may represent oxygen isotope Stages 7, 9, and possibly 11 .

3. Biostratigraphy, magnetostratigraphy, and sedimentation-rate constraints used to date the top of the MTDs suggest that: (a) the deep EMTD was last active at $\sim 33 \mathrm{ka}$, and (b) the Unit R MTD was last active at $\sim 45 \mathrm{ka}$. Although these dates are ten- 
tative, biostratigraphic data indicate that the two deep MTDs were active at different times, before and after $40 \mathrm{ka}$.

4. From biostratigraphy and seismic correlations, it is suggested that the Eastern and Western near-surficial Debris Flows were last active during the transition period between the last glacial and the Holocene.

5. It is suggested that climatically induced sea-level lowerings were the cause of the deep MTDs. In addition, it is suggested that sea-level rise and/or peak Amazon River discharge from Andean deglaciation were the causes of the near-surficial debris flows. It is noted that decompression of gas hydrates, critical sediment loading, and submarine earthquakes could also be causes of the MTDs.

\section{ACKNOWLEDGMENTS}

We would like to thank Jan Backman, Michael Sarnthein, David Bukry, and especially Jacques Giraudeau for their support and advice. We would also like to acknowledge the technical support of Birgit Jørgensen, and the funding provided by the Danish National Science Research Council, the DFG (Deutsche Forschungs Geowissenshaft), and the Department of Geography, UCL. We appreciate constructive reviews by Jan Backman, Jim Cullen, and Larry Peterson.

\section{REFERENCES}

Bouma, A.H., Coleman, J.M, Meyer, A.W., et al., 1986. Init. Repts. DSDP, 96: Washington (U.S. Govt. Printing Office).

Bukry, D., 1973. Low-latitude coccolith biostratigraphic zonation. In Edgar, N.T., Saunders, J.B., et al., Init. Repts. DSDP, 15: Washington (U.S. Govt. Printing Office), 685-703.

, 1978. Biostratigraphy of Cenozoic marine sediment by calcareous nannofossils. Micropaleontology, 24:44-60.

Castro, J.C., Miura, K., and Braga, J.A.E., 1978. Stratigraphic and structural framework of the Foz do Amazonas Basin. Proc. Annu. Offshore Technol. Conf., 3:1843-1847.

Cochran, J.R., Stow, D.A.V., et al., 1990. Proc. ODP, Sci. Results, 116: College Station, TX (Ocean Drilling Program).

Curry, W.B., Shackleton, N.J., Richter, C., et al., 1995. Proc. ODP, Init. Repts., 154: College Station, TX (Ocean Drilling Program).

Damuth, J.E., and Fairbridge, R.W., 1970. Equatorial Atlantic deep-sea arkosic sands and ice-age aridity in tropical South America. Geol. Soc. Am. Bull., 81:189-206.

Damuth, J.E., Flood, R.D., Kowsmann, R.O., Belderson, R.H., and Gorini, M.A., 1988. Anatomy and growth pattern of Amazon deep-sea fan as revealed by long-range side-scan sonar (GLORIA) and high-resolution seismic studies. AAPG Bull., 72:885-911.

Damuth, J.E., and Kumar, N., 1975. Amazon Cone: morphology, sediments, age, and growth pattern. Geol. Soc. Am. Bull., 86:863-878.

Ericson, D.B., Ewing, M., Wollin, G., and Heezen, B.C., 1961. Atlantic deepsea sediment cores. Geol. Soc. Am. Bull., 72:193-286.

Ericson, D.B., and Wollin, G., 1956. Correlation of six cores from the equatorial Atlantic and Caribbean. Deep-Sea Res., 3:104-125.

, 1968. Pleistocene climates and chronology in deep-sea sediments. Science, 162:1227-1234.
Flood, R.D., et. al., 1995. Introduction. In Flood, R.D., Piper, D.J.W., Klaus, A., et al., Proc. ODP, Init. Repts., 155: College Station, TX (Ocean Drilling Program), 5-16.

Flood, R.D., Piper, D.J.W., Klaus, A., et al., 1995. Proc. ODP, Init. Repts., 155: College Station, TX (Ocean Drilling Program).

Heezen, B.C., and Ewing, M., 1955. Orléansville earthquake and turbidity currents. AAPG Bull., 39:2505-2514.

Manley, P.L., and Flood, R.D., 1988. Cyclic sediment deposition within Amazon deep-sea fan. AAPG Bull., 72:912-925.

Mikkelsen, N., and Maslin, M.A., in press, Reconstruction of the sedimentary history of the late Quaternary Amazon Fan Complex. Geol. Soc. Spec. Publ. London.

Milliman, J.D., and Meade, R.H., 1983. World wide delivery of river sediment to the oceans. J. Geol., 91:1-21.

Okada, H., and Bukry, D., 1980. Supplementary modification and introduction of code numbers to the low-latitude coccolith biostratigraphic zonation (Bukry, 1973; 1975). Mar. Micropaleontol., 5:321-325.

Pflaumann, U., Duprat, J., Pujol, C., and Labeyrie, L.D., 1996. SIMMAX: a modern analog technique to deduce Atlantic sea surface temperatures from planktonic foraminifera in deep-sea sediments. Paleoceanography, 11:15-35.

Prell, W.L., and Damuth, J.E., 1978. The climate related diachronous disappearance of Pulleniatina obliquiloculata in Late Quaternary sediments of the Atlantic and Caribbean. Mar. Micropaleontol., 3:267-277.

Pujos, A., and Giraudeau, J., 1993. Répartition des Noelaerhabdaceas (nannofossiles calcaires) dans le Quaternaire moyen et supérieur des océans Atlantique et Pacifique. Oceanol. Acta, 16:349-362.

Raffi, I., Backman, J., Rio, D., and Shackleton, N.J., 1993. Plio-Pleistocene nannofossil biostratigraphy and calibration to oxygen isotopes stratigraphies from Deep Sea Drilling Project Site 607 and Ocean Drilling Program Site 677. Paleoceanography, 8:387-408.

Showers, W.J., and Bevis, M., 1988. Amazon Cone isotopic stratigraphy: evidence for the source of the tropical meltwater spike. Palaeogeogr., Palaeoclimatol., Palaeoecol., 64:189-199.

Takayama, T., and Sato, T., 1987. Coccolith biostratigraphy of the North Atlantic Ocean, Deep Sea Drilling Project Leg 94. In Ruddiman, W.F., Kidd, R.B., Thomas, E., et al., Init. Repts. DSDP, 94 (Pt. 2): Washington (U.S. Govt. Printing Office), 651-702.

Thierstein, H.R., Geitzenauer, K., Molfino, B., and Shackleton, N.J., 1977. Global synchroneity of late Quaternary coccolith datum levels: validation by oxygen isotopes. Geology, 5:400-404.

Thompson, L.G, et al., 1995. Late glacial stage and Holocene tropical ice core records from Huascaran, Peru. Science, 269:46-50.

Tiedemann, R., Sarnthein, M., and Shackleton, N.J., 1994. Astronomic timescale for the Pliocene Atlantic $\delta^{18} \mathrm{O}$ and dust flux records of Ocean Drilling Program Site 659. Paleoceanography, 9:619-638.

Weaver, P.P.E., 1993. High resolution stratigraphy of marine Quaternary sequences. In Hailwood, EW.A., and Kidd, R.B. (Eds.), High Resolution Stratigraphy. Geol. Soc. Spec. Publ. London, 70:137-153.

Weaver, P.P.E., and Thomson, J., 1993. Calculation erosion by deep-sea turbidity currents during initiation and flow. Nature, 364:136-138.

Date of initial receipt: 5 December 1995

Date of acceptance: 26 June 1996

Ms 155SR-220 